\title{
A cause still unwon: the struggle to represent Scotland
}

\section{Neil Blain and Kathryn Burnett}

\begin{abstract}
As far as Mr Weir could make out, arriving when conversation was fairly floated, somebody (probably the LORD ADVOCATE) had devised and was administering a system of indentured labour in the Hebrides. The terms of engagement, he gathered, involved a condition of repatriation. Now that is a thing no Scot who respects himself and truly loves his country will submit to. He will cross the Tweed, come to London, become in turn Prime Minister and Leader of the Opposition, or vice-versâ. But repatriation he will not submit to. (Essence of Parliament, Punch, 20 February 1907:140¹)
\end{abstract}

\section{All that's best in Britain}

An edition of Lilliput magazine ${ }^{2}$ from precisely the middle of the twentieth century carries an advertisement for the Standard Vanguard saloon. It is part of a series of advertisements featuring 'All that's best in Britain' and features a half-page, lowangle, upper-body colour shot of a piper in semi-profile, in full Highland military dress with bearskin hat and a white cockade; whose bagpipes fill most of the frame. Lit strongly to the face, he is framed against a background of blue sky. The copy fills the third quarter of the page, above a line drawing of a Standard Vanguard saloon: 


\section{Britain...}

Scotland, land of glens and lochs, of rich lowlands and thriving cities has reared on its soil a hardy, purposeful people - builders, explorers and engineers whose work forms part of our great British heritage.....the same qualities of craftsmanship and enterprise are to be found in the products of the Standard Motor Company, representing as they do in every detail of their design 'all that's best in Britain'. (Lilliput July 1950: 109)

The 'All that's best in (or "from") Britain' strapline, which made reference to the themes of the Festival of Britain on either side of that event, was also used in an advertising series for the Triumph Mayflower and the Triumph Renown, featuring various 'national' emblems such as a mounted guardsman, Morris dancers, artisanal labour and royal pageantry. Another Standard Vanguard advertisement in the series 'All that's best in Britain' features Saxon heritage: 'from time immemorial a horn has been blown each evening in the town of Ripon...a survival of the Saxon Wakeman's curfew call...linking us with a past that saw the building of the great cathedrals and manor houses by craftsmen who strove for nothing less than the best' (June 1950:8); the photograph this time is a monochrome shot of the hornblower, in tunic and tricorn hat.

The dichotomy evident in much advertising of this period, between a modern Britain boasting industrial and scientific capacity, yet also feeling a nostalgic yearning for a quieter time before the world wars, produces on the one hand soporific images of the past, for example, a line drawing of a tranquil cricket game on an English 
village green, for Regent Motor Spirit, under the strapline 'The Spirit of the Nation'. On the other, we might find the 'Britain leads' series for Wills's Gold Flake cigarettes, focusing not just on Britain's accomplishments in the established technologies of shipbuilding and television ('research and inventiveness of a very high order enabled Britain to be the first country in the world with television') but also in the developing field of jet propulsion, looking forward to the economic struggles of the reconstruction period.

Alongside this assimilative approach there is periodically revealed a glimpse of an alternative account of Scottishness. A Lilliput cartoon of April 1950 features an elderly kilted Scotsman of forlorn appearance who has opened a letter in his front hall, the caption reading 'Dear Sir, or Madam...'. He seems to be considering these alternatives depressively (1950: 89).

Six years after Lovat's commando brigade had been piped ashore in Normandy on D-Day, the piper in the Standard Vanguard advertisement represents a dimension of Britishness with a specific history, associated (say) with those Highlanders the sound of whose bagpipes brought (premature) hope to the besieged inside the Residency at Lucknow. He operates as a conventional symbol of Scotland, but his semiological functioning is more complex than it appears, and his Highland garb is not the primary meaning of the text. We discover at worst a less restrictive stereotype ('a hardy, purposeful people - builders, explorers and engineers') than the image at first suggests, despite its limitations. Though it is significant that a piper represents 'builders, explorers and engineers', rather than, say, an engineer, this is a function of the general nostalgia of 'All that's best in Britain': 'industry', in another advertisement, is represented by a wheelwright rather than a jet propulsion engineer. The image is complex rather than simple (the cartoon, taking its Scottish identifiers 
from much the same reservoir of images, is merely a joke about a man in a skirt). The Standard Triumph advertisement, while framing the Scots as 'a people' (perhaps in this context 'an ethnicity') and therefore different from the English, simultaneously accounts for them as a component of Britishness and as producers of British heritage, whereas the cartoon belongs to a repertoire of difference.

Yet both Scottish texts assert difference. Ripon's hornblower is not constructed as belonging (say) to a gritty, resourceful Yorkshire 'people'; his Englishness is selfevident (his subjectivity is aligned with that of an English reader) and need not be accounted for. It is enhanced by reference to a 900 year-old extant tradition which 'began in Saxon times', the category of 'Saxon' being in such accounts coterminous with 'English'. In an alternative and more persuasive history, the Scots, Danes, Northumbrians and Normans all complicate this tranquil myth of Ripon's 'Saxon' continuities; but nation-building (and car sales) involve much simplification. These simplifications, however, create a durable currency.

\section{Groundskeeper Willie and the Baron of Bradwardine: characterizing Scotland}

'Hie to the house, Rose, and see that Alexander Saunderson looks out the old Châteaux Margoux (sic), which I sent from Bourdeaux to Dundee in the year $1713^{\prime} . . . '$ We cannot rival the luxuries of your English table, Captain Waverley, or give you the epula lautiores of Waverley-Honour - I say epula rather than prandium, because the latter phrase is popular; Epulae ad senatum, prandium vero ad populum attinet, says Suetonius Tranquillus. But I trust you will applaud my Bourdeaux; c'est des deux oreilles, as Captain Vinsauf used to say 
- Vinum prima notae, the Principal of St Andrews denominated it. (Scott, 1860: 178)

There's honey, Christmas cake, heather, a whole fruit bowl of citrus tones, smokiness, syrup, peat (usually fairly elusive, but poking its head out of the thickets of other tastes now and again), vanilla, leather, straw, ginger and even other sorts of wood beside the oak you'd expect in there; cedar is one, and I thought I smelled something like the balsa wood we used for the initial few lessons in first-year woodwork class. ${ }^{3}$ (Banks 2003: 260 )

Colour is a rusty, radioactive orange. Nosing reveals a bouquet of bubble gum and something vaguely citrussy, maybe tangerine? Carbonation is medium, and mouth-feel...well, you can almost feel the enamel dissolving on your teeth. $^{4}$ (The Travel Book 2005: 345)

Writer of Trainspotting to take up cudgels for deep-fried Mars bars in culinary book with Scottish slant. ${ }^{5}$

(Gibbons: 2003)

Glasgow had in the 1890s a loose equivalent of Punch, namely Quiz magazine. ${ }^{6}$ One of its correspondents notes that 'Punch, or the "London Charivari", has often been able to crush by ridicule abuses and follies that seemed proof against argument. Why should not Quiz, or the "Glasgow Charivari”, do likewise? (Quiz, 22 August: 249). Glasgow's confidence blazes from the pages of Quiz, displaying a Victorian optimism 
and poise which in Britain now is thought of as an American characteristic. That parallel also applies to Quiz's sparing focus on the appalling social conditions on which Glasgow's wealth was based: 'one of the regretful features of city life is a separation of the classes that seems to create a west-end and an east-end in feeling as in social position' (15 August: 236).

Its editorial (these are penned under the authority of 'Quiz Office') of 18 July 1890 focuses on the danger of steamers racing each other on the Clyde:

The Clyde has a reputation unequalled in the world for its river steamers. One only requires to sail on the Thames or the Mersey to see how far ahead we are in this matter. It is right that everything should be done to sustain this reputation, and the steamers that have recently been added to the fleet are undoubtedly in the line of progress. They are finer steamers than their predecessors and undoubtedly, take them all over, swifter as well. The outcome of the recent changes in the coast traffic has been a break-neck competition against which, when carried too far, Mr Quiz must protest. That it has been carried too far of late all who travel must have noticed. An amount of personal feeling has entered into it, and if some kind of check is not put on it, we may be carried to - the bottom, in a remarkably short time from the city. (p. 197)

A fortnight earlier (4 July), the editorial has sent a message of congratulations to the United States on the anniversary of the Declaration of Independence, speaking for Britain generally, noting that 'there is much in each country from which the other may learn, and in a healthy rivalry in the arts of peace between Britain and America much 
of the progress of the world lies'. 'May nothing', it concludes (p.177) 'ever arise to affect the friendly relations now existing!'. Quiz makes many references to American stories and events, New York being as much within its view as London. There are occasional nods to the large northern English cities as in some sense members of a community. Overall, Quiz is as often cosmopolitan as parochial, alert and engaged in the face of international currents and events. Its 'Under the Reading Lamp' column (14 March) typically notes that 'Mr Arthur Severn' has given an authoritative contradiction to the malicious statement regarding Mr Ruskin made by the New York Herald recently. I should give a good deal to have Mr Ruskin's opinion on the style of journalism represented by the New York Herald. It would be a choice bit of English composition I feel certain' (p. 19).

Wherever Quiz may be willing to acknowledge that Glasgow is still underdeveloped, it cheerfully assumes that the city will attend to it:

Notwithstanding all those excellent features of our civic administration, which have caused Glasgow to be held up as an example to the world, we must admit that in the cultivation of what may be called the social side of our municipal life, on any large scale, we have hitherto been lacking... The significance of Tuesday evening's assemblage, in view of this, is important, and we have no doubt that the Lord Provost's ball, or some such gathering, will now be regarded as an institution while Glasgow continues to flourish. (14 March: 17) 
Quiz generally presents a view of cultural life in which engagement with London is taken for granted, exhibitions and other London events being routinely handled. There is some ambivalence over the competitive aspects of the relationship. Town Tattle (28 March) expresses the wish that when Glasgow's new art galleries are 'set agoing', they will have a Print Room similar to those in the British Museum or South Kensington. The framing of the matter barely dwells on Glasgow's as yet less developed state before briskly suggesting a solution: 'It is hard on the Provinces, that when any comparison falls to be made, it must of necessity be in London. Duplicates from British Museum or South Kensington might be arranged for' (p.35). Even this modesty is intermittent. The same feature has reported a week earlier that Century magazine of that month contains an article which declares that Glasgow occupies 'not the second, but the first place among the communities of Great Britain' as a 'distinct and complete municipal organization' (p.25). Quiz Office later reports (2 May 1890) that 'Greater Glasgow' will cover a municipal area of 25 square miles, with the combined populations of Manchester and Birmingham, 'and 180,000 more than Liverpool' (p. 86) and notes that Glasgow's claims to be Capital of Scotland are strengthened by such great expansion. In another edition (23 May) the commentary generously congratulates the Corporation of Dublin on its erection of quality housing for the poor (p. 117), noting that Glasgow could usefully follow suit, and likewise (29 August) on the occasion of a visit by Gladstone to Dundee, while regretting that he was not to 'come West, as was at one time expected he would', congratulates 'the citizens of Dundee on the visit they will have, and on their decision to present the right hon. gentleman with the freedom of the city. What a friend gets is not lost' ( $p$. 257). 
That 'east-end of feeling' which Quiz regretfully sees as an intrinsic feature of city life would eventually have more of the stage in Glasgow's representation, both of itself and by outsiders, than was imaginable in 1890. When Glasgow's newly formed anti-litter squad took to the streets in 2007, infamously, in knife-proof vests, in a city by then frequently characterized as the 'murder capital of Europe', Glasgow had already been the subject of extensive academic and journalistic discussion focusing, especially, on dual, contrastive late-modern accounts discernible by the start of the 1990s. Both these accounts display historical continuities. One, the pejorative Glasgow of multiple deprivation and crime, is continuous with a Glasgow which had from the time of its rapid nineteenth century growth produced some of the worst social conditions in the world, with corresponding myths of the menace of the Gorbals and the post-war housing estates. The other, the postmodern city of service sector growth and cultural charms, is the downsized descendant of Quiz's Glasgow of progressive municipal development and investment in education and the arts.

There is no prima facie case for expecting that indigenous cultural production will produce positive accounts of local conditions, or that the typifications produced by outsiders will be negative. Cultural histories, of the novel, or the film, or of broadcasting, can be used selectively to prove both that proposition and the opposite. To generalize about the creative and gatekeeping mechanisms which engender or permit certain representations of cities and countries is difficult. Today, the crucial function of commissioning editors in broadcasting, who in the UK remain generally in London, is central to the decision about which kinds of productions (and with what contents and forms) reach public consumption of television (radio has more flexibility). In the newspaper press, including Internet publishing, editors, news agencies and journalists are all part of the process of selection, while magazines and 
consumer guides conform to their own editorial habits. The tendency wherein accounts of localities narrow to what are known as 'stereotypes' is very well established. A broader cultural conservatism which may be inherent in that narrowing is given further emphasis by editorial proclivities in the media, to stick with what is known, lest the audience desert.

If we try to understand why Rab C Nesbitt is to Glasgow what Frasier is to Seattle, the answer will be a complex mixture of economics, ideologies, politics, the expectations of commissioning editors, and half a dozen less accessible factors in the creative and production mix, including the headquartering of most of the Scottish media in Glasgow. ${ }^{8}$ Rab C. is part of a much later industry of the demotic in Glasgow, and of a usurpation of Scottish identity by a stunted version of Glaswegian identity. If a waiter or a bartender in Hong Kong or Santa Fé should offer, as sometimes they will, his or her Scottish impression, there's a good chance it will be working class Glaswegian (at least aspirationally; one of the present authors can attest to a stage production of Brigadoon in an American university of which the director - challenged on the authenticity of the pronunciation of 'up' as 'oop' - responded that the cast had listened very carefully to tapes of Scotty in Star $\left.\operatorname{Trek}^{9}\right)$. Some representations wield more power than others, and in different domains. For example, the American screen will tend to have disproportionate influence internationally. The comic grotesque, Fat Bastard (one of a number of personae of Mike Myers in the Austin Powers series) may be placed in company with The Simpsons' Groundskeeper Willie, Mel Gibson's Wallace, Mrs Doubtfire, Shrek, and others, as figures egregiously bearing Scottish identity abroad without (as it were) permission. But whether there is anything more 'authorized' about My Ain Folk, Cracker, One Foot in the Grave, Taggart, Morvern Callar, Red Road or any other examples containing more apparently material Scottish 
dimensions, is purely a matter of belief. What constitutes the 'national' dimension is in practice always hard to determine in film and television since the search implies looking for signs of cultural geography across many elements of production (commissioning, script, finance, location, creative and professional roles) and distribution. Fat Bastard's indigenous credentials don't seem quite as good as Dr Finlay's but that is only the beginning of an argument, for example about which of them better represents what, where, and to whom.

When the Baron of Bradwardine offers Waverley a bottle of his cherished Châteaux Margaux, the authorial ironizing on such a show of cosmopolitanism barely undermines the sense of culture which emerges from the display, a diversity and texture in Scottish history which the irony merely underscores. Shipped to Dundee six years after the Union, this wine holds a memory of a Scotland with its own European history, its ambassadors and schools and colleges in Paris and Rome. The visitor from England is juxtaposed beside European counters of Scottish identity. The quantity of forgetting involved in the narrow accounts of history and culture which are all that are generally now risked in broadcasting and most of the press in both Scotland and the UK generally is depressingly great. As time goes on, narrowcasting may in part be compensating for this, not least through the Internet, though it too has its limiting editorial habits (if and how radio may further develop in the DAB era is still to be seen). But where journalists and editors are prepared to work endlessly with the currency of banal and repetitive jingles, mapping 'deep-fried Mars bars' and fish suppers onto what is literally and figuratively a complex menu, they tend, as they do through their dependence on 'human interest' and celebrity culture, to treat real histories as a specialism not for their profession. Likewise, the caution of commissioning editors, unable, four hundred miles away from the Central Belt of 
Scotland, to accept that more than the narrowest versions of Scotland make good drama or comedy, greatly restricts the accounts available. ${ }^{10}$ There are parallels, too, for the financing of film; ${ }^{11}$ and for the newsworthiness which Scotland can command in England. And when representations become based as much on other representations as on anything material in a local culture, they are both narrowed and exaggerated, seeming also to reach a critical mass which makes alternative discourses more difficult, for a variety of reasons, to venture.

Indigenous accounts from the eastern end of the Central Belt have been as savagely critical of Scottish culture as anything dreamt of in the west. The capital's most celebrated detective in literature and television, Ian Rankin's Rebus (a fish supper man, who really prefers tobacco and alcohol to food) is the bleakest of cultural observers both of his native Edinburgh and Scotland in general; and the celebrated and lethal strikes against Scotland and Scottishness in Irvine Welsh's Trainspotting (somewhere else not to eat out) are as succinct a response as possible to the bad faith inherent in Scotland's negotiation of its relationship with England. These attributions from within raise a further question.

\section{A Scotland in whose interests?}

The BBC's independently-produced Restoration (subsequently Restoration Village) TV project, which ran from 2003 until 2007, offered local communities the opportunity to enter endangered or dilapidated buildings (after local selection) into a 'national' contest, for viewers' votes, to win substantial Lottery funds for reconstruction or refurbishment. Central to the project was the need for management of 'local' and 'national' references informing the symbolic and economic commoditization of each building. 'Placing' the past, through the selection of 
buildings and the narratives constructed in relation to them, required much the same duality as is at work in the piper's image in Lilliput. Buildings not in the Home Counties required to be framed as differentiated in terms of cultural geography and local history, so that they might offer sufficient interest and entertainment, formally presented within discourses of travel and tourism. Yet Restoration's discursive practice requires the mediation of all 'otherness' such that 'local' and 'regional' particularities are wholly encompassed by an established national context within which to understand 'British' heritage. A building on Orkney requires to be at once relatively exotic, local and particular, and simultaneously to participate in a British heritage which includes a swimming baths in Manchester.

The fourteenth century Portencross Castle sits between the small Ayrshire town of West Kilbride (about 30 miles southwest of Glasgow) and the Hunterston A and B nuclear power stations (the former now being decommissioned). The castle is roughly five miles north of the mini-conurbation of Saltcoats, Stevenston and Ardrossan (which contains significant multiple deprivation). Restoration visited the site in 2004, constructing a very different topography and cultural geography. The television sequence begins with a shot of the presenter in hilly terrain next to the Faslane nuclear base, relatively distant from West Kilbride, but apparently selected to initiate a military motif, beginning with glamorous Top Gun-style shots (with musical theme) of military helicopters and jet fighters (preceded by standard references to mountain, heather, and 'endless vistas of glittering water'). We learn that all Britain's nuclear weapons are kept here because of the particularities of Scotland's access to the Atlantic. 
The narrative then moves from Scottish, to British, back to Scottish military history in an almost undetectable slippage, the nuclear deterrent becoming an element in the continuity of Scottish defences of the Clyde estuary:

The Clyde has in fact long been viewed as a vital strategic sea route. Even today it's home to the Faslane naval base. All of Britain's nuclear weapons are kept here because it's the ideal location for nuclear submarines to slink out into the Atlantic Ocean. But the military importance of the Clyde to the Scots is hardly a modern invention. And it's hardly surprising that as early as 1360 they decided to build a defensive watchtower to keep an eye on the sea routes favoured by the invaders.

This statement simultaneously conflates and confuses Faslane's Scottish and British dimensions.

It also foreshortens Scottish history, since it had occurred to natives of Scotland to build coastal fortifications against invaders perhaps fifteen hundred years before the Battle of Largs between the Scots and King Haco's invading Norwegians, which latter event occurred very near Portencross in 1263 . Someone must have already built a watchtower there too or else the Scots (who won) would not even have known that the Norwegians were approaching. (As it happens Faslane, unlike Portencross, is in Argyll, which having more coastline than France, required sea fortifications everywhere.)

A difficulty within London institutions, when defining the values attaching to Scotland's status within the UK, both preceded the Union and has more recently comprised a broader tendency to which media institutions, in some respects, merely 
conform. In Restoration, Scotland is a site for cultural visits, but an edition of 2004 focused upon one of Scotland's own explorers, Dr John Rae. There is a developing history of the construction of a 'Scottish national' position on exploration (and indeed on science) from the first half of the nineteenth century. This position operated, however, within specific understandings of Britishness, and of Anglo-Scottish relations (Lewis-Jones 2002; Keighren 2005). Whether within the institutions of the admiralty, or of commerce and science, such Scottish figures conformed to British establishment habits and discourses of their time. Despite that, privileged institutions including the Royal Navy, The Times newspaper, and establishment pillars such as the Royal Geographical Society could where necessary construct a distinction between those who should be held at a distance (literally and figuratively) and those understood to be 'their own' (Burnett and Burnett 2004).

This is most strikingly exemplified in the media cause célèbre of the English explorer Sir John Franklin's ill-fated Arctic expedition of 1845 (fashionably determined to claim for Britain the fabled north-west passage from Atlantic to Pacific). Private allegations of an expeditionary party doomed (for various reasons) to failure, were eventually to be coupled with a public outcry over the 'fate of Franklin's men'. After several search parties were dispatched in 1848 and afterwards, it was subsequently alleged through news accounts that the men had not only perished unnecessarily but in a desperate attempt to survive had 'resorted to cannibalism'. Rae investigated the disaster soon after the event and unwittingly became the public bearer of the news. His report to his employers, the Hudson's Bay Company, contained descriptions of the men's fate provided by 'Esquimaux' (Inuit) who had discovered the bodies of the Franklin party and attested to cannibalism (an allegation subsequently validated by forensic testing decades later). 
A letter of Rae's to this effect was published, without consent, in The Times. The ensuing squall was considerable. The media of the day refused to support such a slur, yet made much of running the story. Spurred on not least by Franklin's widow, newspapers including The Times, and journals like Dickens's Household Words printed much on the topic of the Franklin story, debating the integrity of those involved, most notably focusing on Rae as the deliverer of the Franklin narrative, attacking the morality of the indigenous people and disparaging Rae (McGoogan 2001; Lewis-Jones 2002; Shu-chuan Yan 2006). Dickens himself, writing in Household Words in 1854, leaves little doubt that he finds Rae's conclusions to be illjudged. But Dickens was a consummate media professional of his time and able to work the story more than one way to his own advantage as a public figure; and he magnanimously absolves Rae of blame, even for continuing to believe in the Inuit account ('the word of a savage is not to be taken for it; firstly, because he is a liar...', Dickens 1854: 392) noting among other compliments to Rae that readers should be 'proud of him as an Englishman' (1854: 361). Rae's reputation, however, failed to recover from less balanced assessments.

While Dickens was to observe in the same piece that 'we believe every savage to be in his heart covetous, treacherous, and cruel' (1854: 362), Rae's affinity with the Inuit - in his time he was thought to have 'gone native' - stands out in strong contrast. ${ }^{12}$ His capacity to move beyond the ethnocentrism of his time is forever preserved in the remarkable form taken by his sculpted figure on the monument in St Magnus Cathedral in Kirkwall, displaying Rae as ever the fieldman, clothed in his arctic workgear, with his rifle, as though dozing after reading the book on which his rifle rests. Here is a man at one with his arctic environment yet reclaimed at the centre of his Orkney homeland (Burnett and Burnett 2004). Having lived until he was 80, Rae died 
without a knighthood, quite exceptionally for an explorer of great achievement, not having been the beneficiary of an inclusiveness of vision to match his own.

In 2004, Restoration visited the Rae family home in Orkney, the Hall of Clestrain, in Orphir. As with Portencross, the question clearly arose for the producers of how best to construct the story of the house for the TV audience. Restoration combines two accessible sub-narratives. First, the history of this ruined private building acquires some personalisation, leading to an account of John Rae and his childhood at Clestrain, the biographical account of a boyhood life nurturing an ability for seafaring, exploration and an identity with 'the North', to explain Rae's later Arctic adventures. $^{13}$

But this story in some respects competes with a separate cultural history of the House itself. The Hall of Clestrain is presented as an example of 'Georgian reach' to the 'remote' and 'unbelievable' (as one of the presenters puts it) location of Orkney. The interface of the local-national, or periphery-centre axis with the process of memorialising is demonstrated by the correspondence between the 'improbability' of this architectural gem so far to the north, and the 'remoteness' of Rae's achievement to the 'nation'; just as his exploits and their accounts were, in his own lifetime, situated at the margins, sometimes in clear opposition to an Anglo-British discourse and practice of exploration.

What we have seen of the Portencross story already demonstrates some uncertainties in the account of Scottish and British history emerging from London-based media output. However, the narrative which follows the Faslane introduction goes well beyond the merely peripheralizing account of the Hall of Clestrain. It simply relocates Portencross wholesale within a fake construction designed to suggest the remote Highlands and Islands rather than the populated and much-visited Ayrshire coast 
(though the construction of the former as 'remote' is itself metrocentric). Portencross is televisually reconstructed as a castle of the Hebrides or the coasts of the northwest Highlands. It is re-contextualized by shots of sea, and of mountains not in Ayrshire at all: the scene is set by a long lens shot of a mountain in Arran, an hour's boat trip away. All evidence of housing, industrial and recreation complexes on the surrounding Ayrshire coast is kept out of shot. Though Portencross and the coastal walk near it attract many visitors who drive there, and though the area was long ago assimilated within the recreational habits of many of the two million and more inhabitants of Greater Glasgow who can reach it in forty minutes, the programme's experts arrive by boat, constructing an imaginary sense of remoteness. Restoration on this occasion (it was more objective about its subjects in other instances) evidently required traditional Scottish spectacle to balance locations. But there must be cause for anxiety about the willingness of public service broadcasters to treat localities outside London and the Home Counties with this degree of insouciance. This tendency has a long history. Part of it, as already noted, is about institutions.

There is a broader question illustrated by this fabrication, and it is one about the media, representation, and interest. The problems at the core of the "nations and regions' policy adopted by the $\mathrm{BBC}$, and other organizations, are the institutional counterparts of the difficulties evident in the regional vocabulary of television output. The 'nations and regions' tactic ('nations and regions' means 'not London') is a response from institutions reluctant to devolve real power, which construct this offering as a means to retain control in London. 'Nations and regions' proponents (including the regulator, Ofcom) have traditionally been uncomfortable about real divergence across the UK. Regional cooking, local wildlife and folk culture are welcome as constituting difference, but ideological and political difference unnerve 
the ambassadors of the nations and regions policy. The contradictions at the heart of Restoration's treatment of locality partly mirror the asymmetrical relationships connecting media power and media output in Britain. Restoration was a series of visits (and thus highly characteristic) to the British regions from London, visits which generally comprise a one-way ideological and representative process, in which distance is also a one-way phenomenon, from London.

Alternatives to this exterior view don't need to be imagined: even a very modest indigenous approach to Scotland, such as Scottish Television's rural travelogue Weir's Way, which originated thirty years earlier, explored Scotland's internal dimensions both geographically and historically while aligning Scotland quite naturally with a larger world. Weir on one occasion visits Berwick Castle, for example, his narrative quietly suggesting the European dimensions and large scale of Berwick's history, reminding us of how drastically certain lengthy continuities within Scotland's wider identities have been obscured from present experience. The longrunning BBC Scotland television series Eorpa has managed the difficult feat of using the Gaelic medium to thrive as the UK's most cosmopolitan current affairs programme. There is a divide of radical proportions between the Scotland of these indigenous programmes and the Scotland mediated by London.

All the while - and it is a matter of no small importance at a time when the relative economic power of London has further increased, and when competition among cities and regions in the UK to win investment is fierce - the BBC continues to market London nationally and internationally as though it were part of its mission. The Corporation's London-centric nature has seamlessly absorbed digital broadcasting, with offerings on BBC News 24 like Dateline London to place alongside the constant flow of images of London news locations. Streams of London-focused cultural 
programming on BBC Four Television are only periodically interrupted by visits to remote areas like Liverpool and Newcastle, often with an air of self-conscious adventure which seems perennially renewed. (Experiments by London broadcast producers with that most difficult of commodities for the BBC, the English regional accent, tend to favour caricature; but it is true that Scots broadcasters fare better, though often on radio.) Meanwhile, the Scots and Welsh have to assimilate endless references to 'the capital' with a sense of plurality never dreamt of in London. ${ }^{14}$ Sometimes parallel to the interest of public institutions, media industries in the private sector raise additional questions of purpose, which can include a more relentless focus on profit (representation solely with economic purpose) and, where the press is concerned, sometimes also the political will of proprietors and editors. In the world of professional politics, the issue of devolution of media matters to Holyrood, reserved in devolution legislation to Westminster, has been defended by Scottish Labour and is under attack by the SNP, and is therefore a matter of party political contention. Meanwhile, the fact that parts of the Scottish media in the private sector can still be considered Scottish in any sense is often a matter either of contingency, or belief, or both; in other words, where they are so it is only through circumstance, and to determine whether in reality they are or not often requires argument.

It was, however, noted earlier that indigenous cultural production is not linked in any predictable way with patterns of representation. Ideological processes can work to bring external value regimes to indigenous products. In both film and television it has not always been easy to distinguish economic forces from ideological forces in the process of fashioning Scottish screen products which can find a receptive market. Nor is production in Scotland any guarantee of quality. For example, it is arguable 
whether Scotland has come close to producing one quality newspaper with the substance of The Irish Times. It is true that Scotland has maintained the production of four regional dailies with broadsheet origins, as well as producing two serious Sunday newspapers; but a large question haunting demands for greater 'autonomy' for the Scottish media is one of quality.

Scotland exports media professionals, media entrepreneurs, and, by way of takeover by external companies, a number (not all) of its media businesses. This leaves a critical mass question surrounding indigenous creativity, professionalism and production. The complex processes of globalization, specifically of the cultural dimensions of nations, have been impacting upon Scotland in distinct ways. There are in particular very complex patterns of cultural interchange with England, which seem to exhibit both increasing distance and proximity. Among the consequences are that (for example) if Scottish newspapers are not to their readers' satisfaction, then these readers will increasingly read London titles. This has co-existed with increasing demands for political autonomy and an increased sense of cultural separation. These developments are in accord with what we know of postmodern consumer behaviour, in which identities and choices are increasingly laid out like items on a delicatessen counter. (In Scotland, alas, grim inequalities exempt many from entering the store.)

\section{Conclusion: future mediation of the world's best small country}

Weather aside, Scotland, like a fine malt, is a connoisseur's delight - a complex mix of history, culture and arts, festivals galore, feisty people and a wild and beautiful landscape - it should be savoured slowly. (The Travel Book: 345) 
It is not difficult to misrepresent Scotland, and its representation has often been analyzed selectively, too. When this is added to ethnocentric or otherwise ideological accounts of Scottish culture and history (in which anglocentric versions are often to the fore) the resulting discursive knots can be hard to disentangle. The available representations of Scotland form far too complex a range to be subject to careless generalizations. For such a very small country, Scotland has seemed both heavily and contradictorily productive of myth (Harvie: 2002, Gifford and Riach: 2005), at its most extreme being simultaneously the best and worst small country in the world. ${ }^{15}$ Now, however, the question for small national cultures is of visibility, not least to themselves, but also to others, and for a mixture of cultural, political, economic and psychological reasons. Though theoretically the multiple platforms of the digital media world ought to accommodate specialized requirements alike of consumers, producers and communities, digital space does not necessarily work to favour the needs of cultural geographies associated with small nations. 'Narrowcasting' for some specific taste communities (such as for sport, pornography or popular music) can produce revenue, proving commercially attractive (though spare bandwidth is thereby used to replicate, rather than vary, provision). But amidst massive digital expansion it is already evident that locality - depending on factors including critical mass - may lose its viability. Whereas it is commercially attractive, for example, to provide Asian television programming for large dispersed audiences from the Indian sub-continent, so that ethnic minorities in the UK and elsewhere may receive provision in their own languages, this is a function of the size of the audience and of specific cultural needs. 
Across the board, Scottish audiences already consume much of their media product, despite exceptions, from outside Scotland. One challenge posed to indigenous cultural producers in small nations is therefore related to critical audience mass in two ways, through size and preference.

Scotland will continue, probably, to export cultural commodities, including screen product, crucial for economic reasons of profit, infrastructural growth and employment. But it will be a struggle. The viability of media product which contains Scottish cultural themes and contents raises even harder questions (though landscape spectacle and specialized forms of quaintness will no doubt continue to offer their specific appeal). And it is on the Internet, and in mobile phone content, and within new and unpredictable forms of media convergence generally, that the relationship between representation and locality will really be tested. What will be the local contents available on future telephony-based product, for example? Amidst media consumption patterns of the future, the degree of visibility of traditional forms like television (as presently understood) is unpredictable. John Steinbeck's oft-cited riposte to Jackie Kennedy: 'You talked of Scotland as a lost cause and that is not true. Scotland is an unwon cause ${ }^{16}$ is still true in the age of globalization, devolution and digital expansion. ${ }^{17}$ The future role of the media in that process, however the cause turns out, is unclear. The media are not the only carriers of cultural identity, not by far, nor can they deliver their functions as guarantors of local democracy or political transparency in a predictable manner. However, they are politically and culturally very important, and their local dimension is crucial. The Scottish voice is as likely to get lost in the clamour of the digital age as to be heard through new forms of specialized provision. A Scottish media apparatus of sorts exists, unevenly viable across specific media, but its Scottishness is fragile. As with the rest of the apparatus 
of nationhood, there are large questions raised here, about political will, democracy, empowerment, accountability, resources and identity. As with other aspects of our heritage, there are important specific challenges, when faced with the risk of irreversible loss, to engage not only in conservation, but constantly in enterprise and reconstruction.

\section{Notes}

${ }^{1}$ The humorous and satirical magazine published from 1841-2002.

${ }^{2}$ A small-format UK monthly magazine published from 1937-1960 with content ranging from humour to serious arts criticism and short stories, and with much photographic content.

${ }^{3}$ These tasting notes refer to a 30 year-old Macallan single malt.

${ }^{4}$ Tasting notes for Barr's Irn-Bru, reprinted from Lonely Planet's Edinburgh.

${ }^{5}$ On Irvine Welsh's 'defence of the fish supper and the deep-fried haggis'.

${ }^{6}$ Published weekly by W. Weatherston \& Sons, Glasgow, 1881-1898; these samples from the mid-point of its existence in 1890.

${ }^{7}$ Arthur Severn: painter, friend of Ruskin, son of the painter and close friend of Keats, Joseph Severn.

${ }^{8}$ How much more Mr Quiz would have revelled in a local incarnation of the Crane brothers, fighting over opera seats at the Theatre Royal! In his 'Advice to Cads', he affirms (25 July) that 'Glasgow flourished ere ever it saw you', requesting good behaviour of the anti-social when on visits beyond the city; and advising that 'you represent only a section of this community, and that, perhaps, the most contemptible' (p. 206). 
${ }^{9}$ In fact, this pronunciation is not confirmed by further analysis of James Doohan's oeuvre.

${ }^{10}$ The ability of Scottish TV producers to supply network content of high enough quality was controversially challenged by former BBC Chairman and ITV chief executive Michael Grade in 2007, echoed by the Director-General of the BBC.

${ }^{11}$ Though there is a mini-tradition of Scottish film which finds in Europe part of its cultural landscape (Blain 2009).

${ }^{12}$ Indeed his legacy has been his exceptional vision of Inuit indigenous knowledge.

${ }^{13}$ Rae's autobiography (Dr John Rae's Autobiography, unpublished manuscript, Scott Polar Research Institute, ms 787/1) details his island upbringing, positioning this as crucial to his character development and his exceptional capacity for physical challenge (also addressed in his account, 'Roughing It', Boy Life in Orkney, Orkney Herald, 16 February 1887, Orkney Archives).

${ }^{14}$ This would have been doubly a source of anguish to Mr Quiz in Glasgow, who rather assumed that his city was Scotland's real capital.

${ }^{15}$ Scottish airports having first greeted arrivals with the message that Scotland is the 'best small country in the world', it was thereafter dubbed 'the worst small country in the world' by sections of the media in 2007 when it came foot of a league comparing performance indicators in small countries in Western Europe.

${ }^{16}$ In a letter of 28 February 1964. An expanded quotation offers a fuller perspective on the matter. 'I have been thinking about what you said regarding lost causes. And it is such a strange subject. It seems to me that the only truly lost causes are those which win. Only then do they break up into mean little fragments. You talked of Scotland as a lost cause and that is not true. Scotland is an unwon cause.' Steinbeck continues, now referring to the United States: 'Probably the greatness of our country resides in 
the fact that we have not made it and are still trying' (Steinbeck and Wallsten 1975: 795). This framing of the matter makes the prospect of perpetual struggle seem relatively attractive.

${ }^{17}$ By the time Gordon Brown became Prime Minister, and Alex Salmond, First Minister of Scotland, 300 years after the Union (and a hundred years after Punch satirically reflected on how little Scots and Scottish politicians cared for repatriation) the pursuit of another 'unwon cause' had begun to make its force felt in calculations about the future of the UK - namely that of England.

\section{References}

Banks, I. (2003), Raw Spirit: In Search of the Perfect Dram, London: Century, 2003. Blain, N. (2009) 'The visibility of small countries: the Scottish dimension in film and television', in K.Veitch (ed) Scottish Life and Society: A Compendium of Scottish Ethnology, vol. 8: Transport, Communications and the Media, Edinburgh: John Donald, 768-792.

Burnett K. A. \& R. Burnett (2004), 'Scottish polar exploration and the representation of national heroic endeavour (1880-1914)', paper delivered to Visual Culture and Taste in Late Victorian and Edwardian Britain Conference, Centre for Visual Culture in Britain, University of Northumbria, July 15-16.

Dickens, C. (1854), 'The Lost Arctic Voyagers', Household Words, 2 and 9

December.

Gibbons, F. (2003), 'Writer of Trainspotting to take up cudgels for deep-fried Mars bars in culinary book with Scottish slant', The Guardian, Tuesday, August 19, 2003. Gifford, D. and A. Riach (eds) (2004), Scotlands: Poets and the Nation, Manchester: Carcanet Press and Edinburgh: The Scottish Poetry Library. 
Harvie, C. (2002), Scotland: A Short History, Oxford: Oxford University Press.

Keighren, I. M. (2005), 'Of poles, pressmen, and the newspaper public: reporting the Scottish National Antarctic Expedition', 1902-1904. Scottish Geographical Journal $121(2): 203-218$

Lilliput magazine vol 26, nos 1-8, issues 151-158, January-August 1950.

Punch, or The London Charivari magazine, vol. CXXXII, January-June 1907.

Quiz magazine, March 1890 - August 1890.

Scott, W. [1814] (1860) Waverley, Edinburgh: Adam and Charles Black.

Steinbeck, E. and R. Wallsten (eds) (1975) Steinbeck: A Life in Letters, London:

William Heinemann Ltd.

The Travel Book: A Journey Through Every Country in the World, 2005, Victoria, Australia: Lonely Planet Publishing.

Yan, Shu-chuan (2006) 'Voyages and Visions: Imag(in)ing the Arctic in the Victorian Periodical,1850s-1870s' NTU Studies in Language and Literature 53, no. 16, (Dec. 2006), 53-82. 